\title{
Synthesis and reactivity of an unexpected highly sensitive 1-carboxymethyl-3-diazonio-5-nitrimino-1,2,4-triazole $\dagger$
}

\author{
Thomas M. Klapötke,* Andreas Nordheider and Jörg Stierstorfer \\ Received (in Montpellier, France) 18th January 2012, Accepted 3rd April 2012 \\ DOI: $10.1039 / \mathrm{c} 2 \mathrm{nj} 40044 \mathrm{~h}$
}

During the synthesis of functionalized energetic triazole derivatives for biosensor detection devices

1 carboxymethyl 3 diazonio 5 nitrimino 1,2,4 triazole (2) was obtained by nitration of sodium

1 carboxymethyl 3,5 diamino 1,2,4 triazole (1). Zwitterionic (2) behaves like a diazonium cation

which was proved from its reaction with sodium azide by the formation of 3 azido 5 nitrimino

1,2,4 triazole (3). Compounds $\mathbf{1}-\mathbf{3}$ were fully characterized by low temperature single crystal

$\mathrm{X}$ ray diffraction, vibrational (IR/Raman) spectroscopy, NMR spectroscopy, mass spectrometry,

elemental analysis and DSC measurements. The sensitivities were determined by the BAM drop

hammer, BAM friction tester and an electrostatic discharge device. The extremely high impact

sensitivity of the diazonio compound in comparison to its azido analogue is explained by the use

of electrostatic potentials.

\section{Introduction}

In the area of energetic materials research, insensitivity, sustain ability and detection of explosives have gained considerable interest over the past years and especially ecological aspects have become more and more important. For example, ongoing research tries to find suitable lead free primary explosives in order to replace lead azide and lead styphnate in primary compositions. Moreover RDX shows significant eco and human toxicity and research is underway to find suitable alternatives for this widely used high explosive.

The increasing number of terrorist attacks and efforts using explosives has demonstrated the need for methods to screen a wide range of explosive materials and demonstrate whether or not they pose a threat to security. There is also a need to detect and quantify trace levels of explosives contamination on items or surfaces. These trace levels could alert investigators to the possible presence of covered dangerous materials. ${ }^{1}$ The need for fast, highly specific, reliable tests for explosives that can be deployed on a massive scale and produced at a relatively low cost is an important challenge. Systems must be easy to use and require minimal training to operate. Colorimetric tests on a simple basis could provide part of the solution. ${ }^{2}$ Certainly the chemical tests often have a deficiency in the selectivity and specificity demonstrated by biosensors. ${ }^{3}$ Biosensors use biological molecules usually an enzyme, antibody, or nucleic acid to detect sample molecules of interest ${ }^{4}$ via hydrogen bonding,

Energetic Materials Research, Department of Chemistry,

University of Munich (LMU), Butenandtstr. 5 13, D 81377,

Germany.Email:tmk@cup.uni muenchen.de; Fax: +49218077492

$\dagger$ CCDC 843029843031 (1 3). For crystallographic data in CIF or other electronic format see DOI: $10.1039 / \mathrm{c} 2 \mathrm{nj} 40044 \mathrm{~h}$

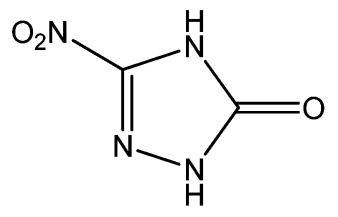

NTO<smiles>Nc1nc([N+](=O)[O-])n[nH]1</smiles>

ANTA
Fig. 1 Popular insensitive secondary explosives based on the 1,2,4 triazole moiety: NTO (5 nitro 1,2,4 triazol 3 one) and ANTA (3 amino 5 nitro $1,2,4$ triazole).

charge charge interactions, and other biochemical interactions. Thus the compounds require functional groups at first, a carboxy or carboxyalkyl group, so that the molecules could be linked to surfaces using amide bridges. Since many new energetic materials such as NTO (5 nitro 1,2,4 triazol 3 one $)^{5}$ and ANTA (3 amino 5 nitro 1,2,4 triazole) ${ }^{6}$ (Fig. 1) are based on triazole heterocycles we tried to combine carboxyl groups with 1,2,4 triazoles connected to other energetic functionalities such as azide, nitro or nitramine groups. During the expected synthesis of 1 carboxymethyl 3,5 dinitrimino 1,2,4 triazole we obtained highly sensitive 1 carboxymethyl 3 diazonio 5 nitrimino 1,2,4 triazole (2), which was fully characterized and reacted to the corresponding azide derivative.

\section{Results and discussion}

\section{Synthesis}

In order to synthesize a triazole derivative with two different energetic groups attached, 3,5 diamino 1,2,4 triazole was functionalized adapting the literature procedure by Einberg, ${ }^{7}$ 

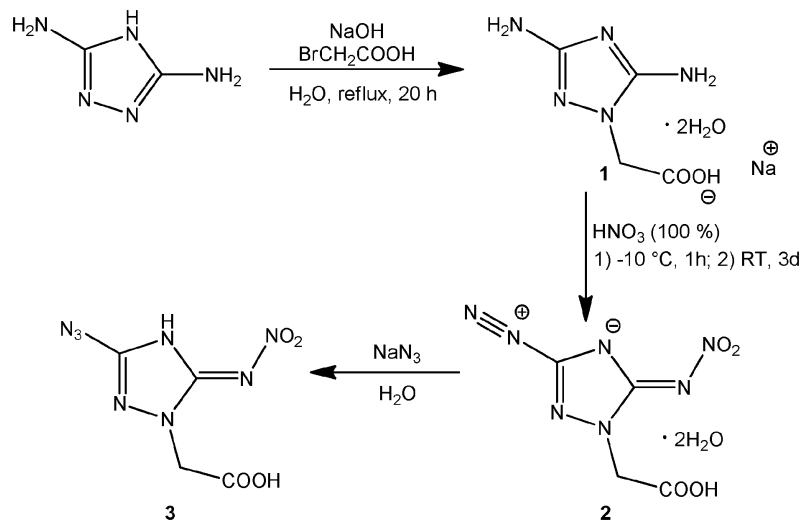

Scheme 1 Synthesis of compounds 13

in which 3,5 diamino 1,2,4 triazole was reacted with bromo acetic acid and sodium hydroxide yielding sodium 1 carboxy methyl 3,5 diamino 1,2,4 triazole dihydrate (1). The neutral compound could not be obtained even after addition of hydrochloric acid until the $\mathrm{pH}$ was below 2. Afterwards 1 was reacted with nitric acid $\left(100 \%\right.$, traces of $\left.\mathrm{NO}_{2}\right)$ at $-10{ }^{\circ} \mathrm{C}$ and stirred for three days at room temperature in order to obtain the corresponding 1 carboxymethyl 3,5 dinitrimino $1,2,4$ triazole. After the mixture was poured onto ice and stored at $0{ }^{\circ} \mathrm{C}$ we obtained orange crystals of 1 carboxy methyl 3 diazonio 5 nitrimino 1,2,4 triazole dihydrate (2) (Fig. 3). This could be due to the presence of $\mathrm{NO}_{2}$ in the nitration mixture. Usually diazonium cations are prepared by the reaction of amines and nitrous acid (nitrous acid is formed by the disproportionation of $\mathrm{NO}_{2}$ in water). Attempts to vary the conditions for this reaction (temperature $0{ }^{\circ} \mathrm{C}, 5{ }^{\circ} \mathrm{C}$; nitration mixtures; sulfuric acid (98\%)/nitric acid (100\%) $50: 50)$ lead to lower yield of $\mathbf{2}$. The expected dinitrated compound could not be isolated or detected. In order to investigate the reactivity of $\mathbf{2}$ and to introduce a second energetic group, $\mathbf{2}$ was reacted with sodium azide in aqueous solution to form 1 carboxymethyl 3 azido 5 nitrimino 1,2,4 triazole (3) in $85 \%$ yield (Scheme 1).

\section{Crystal structures}

Suitable single crystals of the described compounds (1-3) were picked from the crystallization mixture and mounted in Kel F oil, transferred to the $\mathrm{N}_{2}$ stream of an Oxford Xcalibur3 diffractometer with a Spellman generator (voltage $50 \mathrm{kV}$, current $40 \mathrm{~mA}$ ) and a KappaCCD detector using a $\lambda_{\mathrm{MoK} \alpha}$ radiation wavelength of $0.71073 \AA$. All structures were measured at $-100{ }^{\circ} \mathrm{C}$. The data collection and data reduction were carried out with the CRYSAlisPro software. ${ }^{8}$ The structures were solved with SIR 92, ${ }^{9}$ refined with SHELXL $97^{10}$ and finally checked using the PLATON software ${ }^{11}$ integrated in the WINGX software suite. ${ }^{12}$ The non hydrogen atoms were refined aniso tropically and the hydrogen atoms were located and freely refined. The absorptions were corrected by a ScAle3 AbsPack multi scan method. ${ }^{13}$

Sodium 1 carboxymethyl 3,5 diamino 1,2,4 triazole dihydrate crystallizes in the monoclinic space group $P 2_{1} / c$ with four molecules per unit cell. The density of $1.631 \mathrm{~g} \mathrm{~cm}^{-3}$ is slightly lower than that of neutral monoamino 1,2,4 triazole monohydrate. ${ }^{14}$ The triazole ring forms an aromatic planar system involving

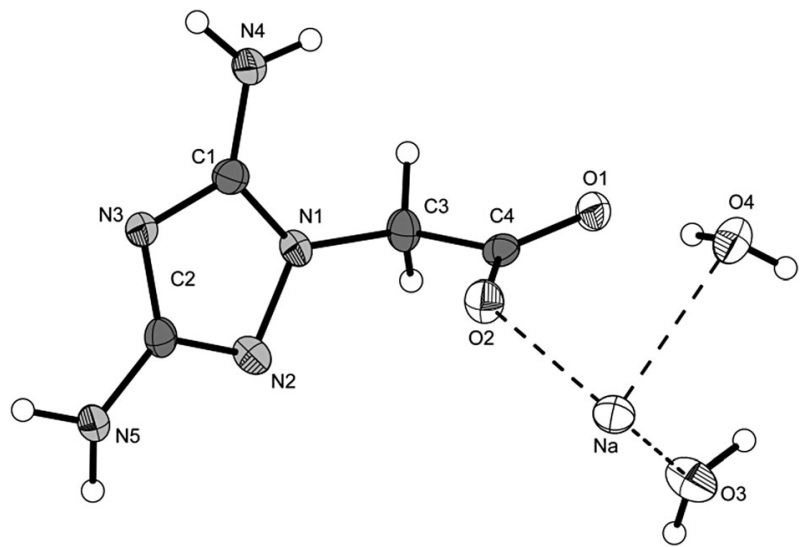

Fig. 2 Diamond plot of the molecular unit of 1. Hydrogen atoms are shown as spheres of arbitrary radius and thermal displacements are set at $50 \%$ probability. Selected distances (A): Na O3 2.319(1), $\mathrm{Na} O 1$ 2.376(1), Na O2 2.392(1), Na O4 2.572(1), O1 C4 1.264(2), O2 C4 1.247(2), N1 C1 1.338(1), N1 N2 1.395(1), N1 C3 1.450(1), N2 C2 1.323(1), N3 C1 1.344(1), N3 C2 1.364(1), N4 C1 1.346(1), N5 C2 1.384(1), C3 C4 1.531(2); selected angles ( $\left.{ }^{\circ}\right)$ : O3 $\mathrm{Na} \mathrm{O} 1$ 92.1(1), O3 Na O2 91.7(1), O1 Na O2 $100.1(1), \quad$ O3 $\mathrm{Na} O 4$ 84.7(1), O1 Na O4 176.6(1), O4 Na O4 86.2(1), O2 Na O4 79.3(1), O4 Na N5 78.5(1), C1 N1 N2 109.9(1), C1 N1 C3 129.3(1), N2 N1 C3 120.4(1), C2 N2 N1 101.5(1), C1 N3 C2 102.7(1), N1 C1 N3 110.1(1), N1 C1 N4 125.3(1), N3 C1 N4

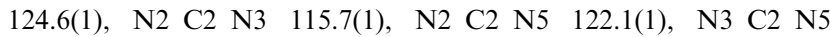
122.0(1), N1 C3 C4 113.9(1), O2 C4 O1 126.2(1), O2 C4 C3 118.8(1), O1 C4 C3 115.0(1).

both amino groups. The $\mathrm{C} 4$ atom of the carboxymethyl group is directed $\sim 90^{\circ}$ out of the plane. The molecular unit of $\mathbf{1}$ is depicted in Fig. 2. The carboxyl group is deprotonated and coordinated to the sodium atom. Two sodium atoms are linked by two water molecules and to one carboxyl group of the diamino molecule building a 3 dimensional network. Ribbons are formed by the parallel molecules, which are connected by the sodium ions. The triazole molecules are linked exclusively by the crystal water molecules.

The title compound 1 carboxymethyl 3 diazonio 5 nitrimino 1,2,4 triazole dihydrate (2) could be isolated in pure and crystalline forms from the reaction mixture. $\mathbf{2}$ crystallizes in the triclinic space group $P \overline{1}$ with two molecules in the unit cell (Fig. 3). The density of $1.671 \mathrm{~g} \mathrm{~cm}^{-3}$ is slightly higher in comparison with the starting material 1 (Table 1). Thus, the azo group seems not to have an observable effect on the density. Few zwitterionic diazonio triazole derivative can be found in the literature. ${ }^{15,16}$ However, to the best of our knowledge only alkylated imidazole diazonio compounds have been reported in ref. 17 . The triazole ring and the nitrimino as well as the azo group form a planar system. The carboxy methyl group leans in the direction of the nitrimino group ( $\sim 75^{\circ}$ out of the ring plane). The nitro amino functionality should be described as nitrimine since the distance $\mathrm{N} 4 \mathrm{C} 1$ of 1.359(2) $\AA$ is significantly closer to a double bond than a $\mathrm{C} \mathrm{N}$ single bond. The remaining proton is deprotonated balancing the zwitterionic molecule with the positive charge at nitrogen N6 and the negative one at the nitrogen atoms N3 or N4 (see electrostatic potential). The packing is again dominated by ribbons. Two molecules of $\mathbf{2}$ are packed together by their 


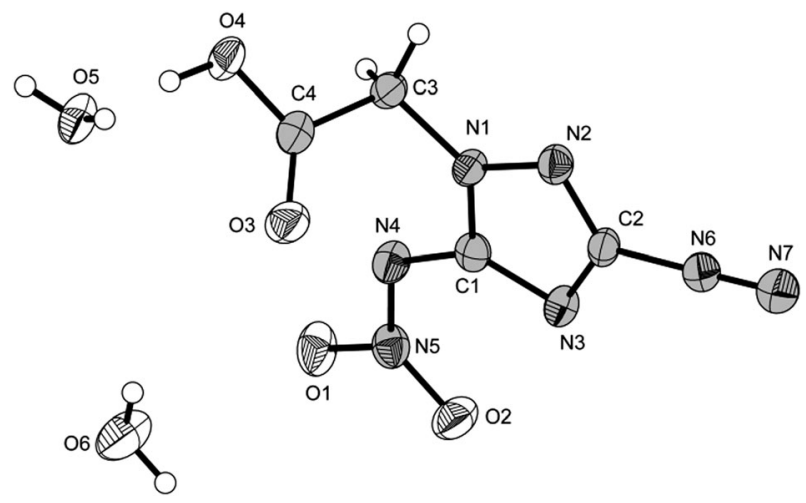

Fig. 3 Molecular unit of 2. Hydrogen atoms are shown as spheres of arbitrary radius and thermal displacements are set at $50 \%$ probability. Selected bond distances ( $₫$ ): N1 N2 $1.350(2)$, N4 N5 $1.329(2)$, N6 N7 1.088(2), N6 C2 1.398(2), N4 C1 1.359(2), N1 C1 1.367(2), N1 C3 1.441(2), C1 N3 1.342(2), N2 C2 1.309(2), N5 O2 1.234(2), $\mathrm{N} 5 \mathrm{O} 1$ 1.260(2), N3 C2 1.337(2), O4 C4 1.307(2), O3 C4 1.202(2), C4 C3 1.512(2); selected angles ( $\left.{ }^{\circ}\right)$ : N7 N6 C2 179.5(2), N5 N4 C1

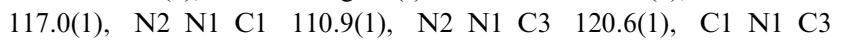
128.5(1), $\mathrm{N} 3 \mathrm{C} 1 \mathrm{~N} 4$ 134.1(2), N3 C1 N1 109.8(1), N4 C1 N1 116.1(2), C2 N2 N1 99.0(1), O2 N5 O1 121.0(2), O2 N5 N4

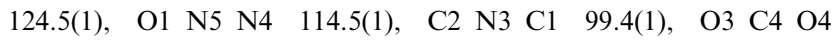
126.2(2), O3 $\mathrm{C} 4 \mathrm{C} 3 \quad 123.1(2), \quad \mathrm{O} 4 \mathrm{C}_{4} \mathrm{C} 3 \quad 110.7(2), \quad \mathrm{N} 2 \mathrm{C}_{2} \mathrm{~N} 3$ 121.0(1), N2 C2 N6 118.2(1), N3 C2 N6 120.8(1), N1 C3 C4 112.1(1); selected torsion angles $\left({ }^{\circ}\right)$ : $\quad \mathrm{N} 5 \quad \mathrm{~N} 4 \mathrm{Cl} \mathrm{N} 3 \quad 5.4(3)$, N5 N4 C1 N1 -177.3(1), C3 N1 C1 N4 3.5(2), C1 N4 N5 O2 4.9(2), N2 N1 C3 C4 $-103.0(2), \quad$ C1 N1 C3 C4 $74.8(2), \quad$ O3 C4 C3 N1 $-5.7(2)$, O4 C4 C3 N1 175.3(1). carboxy groups. The further connection is formed by hydrogen bonds involving both crystal water molecules.

1 Carboxymethyl 3 azido 5 nitrimino 1,2,4 triazole (3) was isolated after recrystallization from water. 3 crystallizes in the monoclinic space group $P 2_{1} / c$ with four molecules per unit cell (Fig. 4). The density of $1.767 \mathrm{~g} \mathrm{~cm}^{-3}$ is higher compared to compound 2. Due to the higher double bond character of the C1 N4 (1.343(2) A) bond and the proton connected to nitrogen atom N3, 3 should also be described as a nitrimino triazole instead of nitr(o)amino triazole. The former proton at nitrogen atom N4 is now found to be connected to the ring nitrogen N3. In addition, the $\mathrm{N} 4 \mathrm{C} 1$ bond length of 1.343(2) $\AA$ is close to a typical $\mathrm{C} \mathrm{N}$ double bond. The shortest $\mathrm{C} \mathrm{N}$ bond in the ring system is between atoms N2 C2 (1.301(2) $\AA$ ). The azide

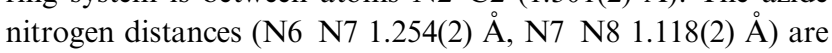
in the range of typical bond lengths found in the literature for organic azides, e.g. for phenyl azide. ${ }^{18}$ In contrast to the structure of $\mathbf{2}$ the crystal packing is formed without inclusion of water which leads to a lower number of hydrogen bonds. This may be a reason for the lower observed decomposition temperature of $125{ }^{\circ} \mathrm{C}$, in comparison to the corresponding diazonium triazole $2\left(T_{\mathrm{dec}} \quad 142{ }^{\circ} \mathrm{C}\right)$. Intermolecular hydrogen bonds are observed between the carboxyl groups of different molecules in the structure of $\mathbf{3}$. In addition, an intramolecular hydrogen bond formed by N3 H3 . O O1 is found. The packing is characterized by layers which are connected through the hydrogen bonds of the carboxyl groups. They interact in the interspace of the parallel orientated triazole rings.

Table 1 XRD data and parameters

\begin{tabular}{|c|c|c|c|}
\hline & 1 & 2 & 3 \\
\hline Formula & $\mathrm{C}_{4} \mathrm{H}_{10} \mathrm{~N}_{5} \mathrm{NaO}_{4}$ & $\mathrm{C}_{3} \mathrm{H}_{7} \mathrm{~N}_{7} \mathrm{O}_{6}$ & $\mathrm{C}_{4} \mathrm{H}_{4} \mathrm{~N}_{8} \mathrm{O}_{4}$ \\
\hline$M / \mathrm{g} \mathrm{mol}^{-1}$ & 215.16 & 249.17 & 228.15 \\
\hline Crystal system & Monoclinic & Triclinic & Monoclinic \\
\hline Space group & $P 2_{1} / c(14)$ & $P 1(2)$ & $P 2_{1} / c$ \\
\hline Color/habit & Colorless cons & Colorless rods & Yellow block \\
\hline Size/mm & $0.30 \times 0.18 \times 0.09$ & $0.40 \times 0.11 \times 0.10$ & $0.29 \times 0.16 \times 0.13$ \\
\hline$a / \AA$ & $9.5655(9)$ & $5.9153(5)$ & $10.3123(7)$ \\
\hline$b / \AA$ & $8.3881(7)$ & $9.1960(8)$ & $6.8821(5)$ \\
\hline$c / \AA$ & $10.9272(11)$ & $9.4344(8)$ & $12.2305(9)$ \\
\hline$\alpha /^{\circ}$ & 90.00 & $93.949(7)$ & 90.00 \\
\hline$\beta /^{\circ}$ & $91.718(8)$ & $90.503(7)$ & $98.873(7)$ \\
\hline$\gamma /{ }^{\circ}$ & 90.00 & $104.609(7)$ & 90.00 \\
\hline$V / \AA^{3}$ & $876.36(14)$ & $495.25(7)$ & $857.61(11)$ \\
\hline$Z$ & 4 & 2 & 4 \\
\hline$\rho_{\text {calc }} / \mathrm{g} \mathrm{cm}^{-3}$ & 1.631 & 1.671 & 1.767 \\
\hline$\mu / \mathrm{mm}^{-1}$ & 0.181 & 0.154 & 0.156 \\
\hline$F(000)$ & 448 & 256 & 464 \\
\hline$T / \mathrm{K}$ & 173 & 173 & 173 \\
\hline$\theta \min \max /^{\circ}$ & $4.26,23.99$ & $4.27,25.99$ & $4.18,25.98$ \\
\hline Dataset $[h ; k ; l]$ & $-7: 10,-9: 9,-11: 12$ & $-7: 7,-7: 11,-11: 11$ & $-8: 12,-8: 8,-15: 15$ \\
\hline Reflections collected & 2707 & 3351 & 4250 \\
\hline Independent reflections & 1325 & 1923 & 1677 \\
\hline$R_{\text {int }}$ & 0.0284 & 0.0218 & 0.0286 \\
\hline Observed reflections & 881 & 1195 & 1125 \\
\hline No. parameters & 100 & 182 & 161 \\
\hline Restraints & 0 & 0 & 0 \\
\hline$R_{1}($ all $) / R_{1}(I>2 \sigma)$ & $0.0547 / 0.0313$ & $0.0625 / 0.0322$ & $0.0557 / 0.0330$ \\
\hline $\mathrm{w} R_{2}($ all $) / \mathrm{w} R_{2}(I>2 \sigma)$ & $0.0519 / 0.0492$ & $0.0556 / 0.0513$ & $0.0705 / 0.0665$ \\
\hline GooF & 0.801 & 0.802 & 0.859 \\
\hline Resd. dens./e $\AA^{-3}$ & $-0.175,0.177$ & $-0.168,0.211$ & $-0.216,0.170$ \\
\hline Solution & SIR 92 & SIR 92 & SIR 92 \\
\hline Refinement & SHELXL 97 & SHELXL 97 & SHELXL 97 \\
\hline CCDC & 843029 & 843030 & 843031 \\
\hline
\end{tabular}




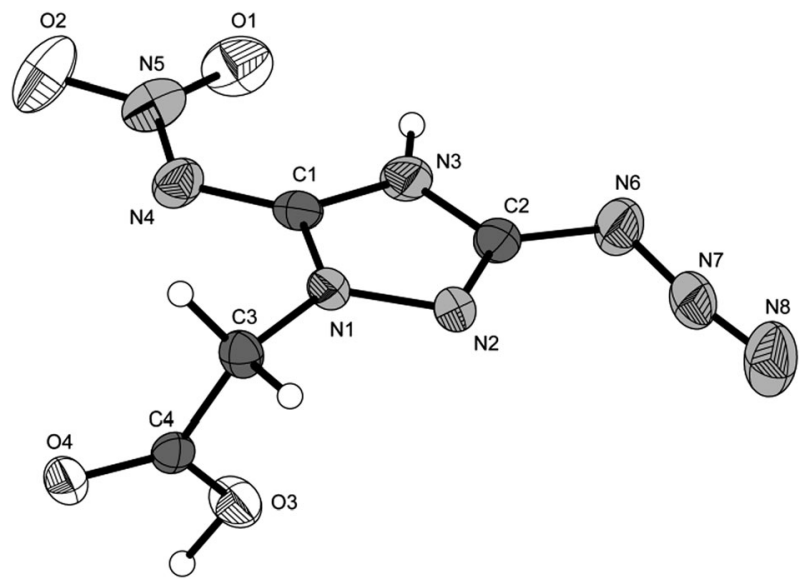

Fig. 4 Diamond plot of the molecular unit of 3. Hydrogen atoms are shown as spheres of arbitrary radius and thermal displacements are set at $50 \%$ probability. Selected bond distances $(\AA)$ : O4 C4 1.235(2), N1 C1 1.339(2), N1 N2 1.384(2), N1 C3 1.450(2), O3 C4 1.294(2), N4 C1 1.343(2), N4 N5 1.348(2), N2 C2 1.301(2), C4 C3 1.503(2), O1 N5 1 246(2), N3 C1 1.350(2), N3 C2 $1.359(2)$, N7 N8 $1.118(2)$, N7 N6 1.254(2), N6 C2 1.388(2), N5 O2 1.236(2); selected angles ( ${ }^{\circ}$ :

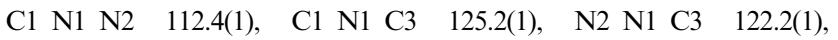

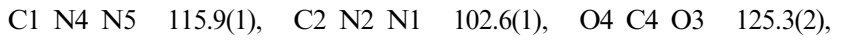
O4 C4 C3 119.8(1), O3 C4 C3 114.9(1), C1 N3 C2 107.0(1),

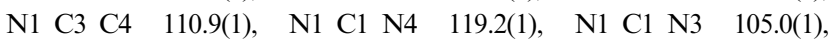
N4 C1 N3 135.8(2), N8 N7 N6 $170.6(2), \quad$ N7 N6 C2 $113.6(1)$, O2 N5 O1 $121.5(2), \quad$ O2 N5 N4 $116.4(2), \quad$ O1 N5 N4 $122.1(2)$, N2 C2 N3 112.9(2), N2 C2 N6 128.2(2), N3 C2 N6 118.9(2); selected torsion angles $\left({ }^{\circ}\right)$ : $\mathrm{C} 1 \mathrm{~N} 1 \mathrm{~N} 2 \mathrm{C} 2 \quad 0.5(2), \quad \mathrm{C} 3 \mathrm{~N} 1 \mathrm{~N} 2 \mathrm{C} 2$ 175.8(1), $\quad$ C1 N1 C3 C4 69.5(2), $\quad$ N2 N1 C3 C4 -105.1(2), O4 C4 C3 N1 -149.4(1), O3 C4 C3 N1 31.0(2), N2 N1 C1 N4 178.8(1), C3 N1 C1 N4 3.8(2), N2 N1 C1 N3 -0.7(2), C3 N1 C1 N3

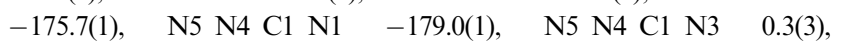

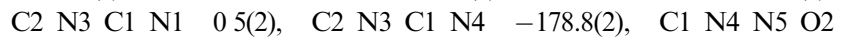

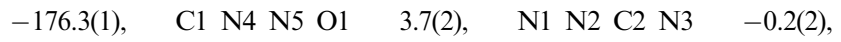
N1 N2 C2 N6 - 178.4(2), C1 N3 C2 N2 $-0.2(2), \quad C 1$ N3 C2 N6 178.2(2), N7 N6 C2 N2 7.4(3), N7 N6 C2 N3 - 170.7(2).

\section{Spectroscopy}

Sodium 1 carboxymethyl 3,5 diamino 1,2,4 triazole dihydrate 1 shows only the $\mathrm{CH}_{2}$ signal in the ${ }^{1} \mathrm{H}$ NMR spectrum at $4.35 \mathrm{ppm}$ as a singlet. The signals of the amino groups could not be observed in DMSO $\mathrm{d}_{6}$ as solvent. The ${ }^{13} \mathrm{C}$ NMR signals of 1 appeared at $169.9 \mathrm{ppm}$ (deprotonated carboxy group), $160.0 \mathrm{ppm}$ and 155.0 (triazole carbons) as well as at 47.5 representing the $\mathrm{CH}_{2}$ group.

The corresponding diazonium compound $\mathbf{2}$ shows also only one singlet in the ${ }^{1} \mathrm{H}$ NMR spectrum at a lower field (4.93 ppm) representing the $\mathrm{CH}_{2}$ group. The carboxy group hydrogen could not be observed due to its very acidic character. In the ${ }^{13} \mathrm{C}$ NMR spectrum most of the signals are shifted to higher fields, compared to the precursor compound 1. Singlets at $167.4 \mathrm{ppm}(\mathrm{COOH}), 155.9 \mathrm{ppm}(\mathrm{CNN}), 151.2 \mathrm{ppm}$ (C nitrimino) and $49.2 \mathrm{ppm}\left(\mathrm{CH}_{2}\right.$ group) were observed. The ${ }^{1} \mathrm{H}$ NMR spectrum of 3 also shows one singlet at $4.81 \mathrm{ppm}$, slightly shifted to a higher field. Most of the ${ }^{13} \mathrm{C}$ NMR signals are shifted to higher fields except the carboxy group signal at $167.8 \mathrm{ppm}$. The singlets are observable at $150.0 \mathrm{ppm}$ and $149.8 \mathrm{ppm}$, representing the triazole carbon atoms and at $48.9 \mathrm{ppm}$ for the $\mathrm{CH}_{2}$ group of the carboxymethyl moiety.
In the IR spectrum of the sodium salt 1 signals at $3362 \mathrm{~cm}^{-1}$, $3278 \mathrm{~cm}^{-1}$ and $3172 \mathrm{~cm}^{-1}$ representing $\mathrm{N} \mathrm{O}$ and $\mathrm{N} \mathrm{H}$ vibrations are observable as well as signals for valence vibrations of $\mathrm{C} \mathrm{H}$ at $2983 \mathrm{~cm}^{-1}$ (Raman: $2984 \mathrm{~cm}^{-1}$ ). The strong vibration at $1582 \mathrm{~cm}^{-1}$ can be interpreted as the bending vibration of $\mathrm{N} \mathrm{H}$ of the amino group. The signal at $1391 \mathrm{~cm}^{-1}$ is assigned to the symmetric valence vibration of the negatively charged carboxyl group. ${ }^{19}$

The IR spectrum of the zwitterionic diazonium compound $\mathbf{2}$ shows $\mathrm{O} \mathrm{H}$ vibrations at $3531 \mathrm{~cm}^{-1}$ (water) and $3298 \mathrm{~cm}^{-1}$. The vibration at $1730 \mathrm{~cm}^{-1}$ can be assigned to the $\mathrm{C} O$ valence vibration of the carboxylic acid moiety. The diazonium $\left(\mathrm{N}_{2}{ }^{+}\right.$substituent) valence vibration appears at $2274 \mathrm{~cm}^{-1}$ as a strong signal (Raman: $2275 \mathrm{~cm}^{-1}$ ). The asymmetric as well as the symmetric vibrations assigned to the nitrimino group are observable at $1522 \mathrm{~cm}^{-1}$ and $1290 \mathrm{~cm}^{-1}$. An almost similar IR and Raman spectrum is observed for compound 3. Referring to this no vibration appears at $2274 \mathrm{~cm}^{-1}$ but at $2153 \mathrm{~cm}^{-1}$ reflecting the valence vibration of the azido group. ${ }^{19}$

\section{Energetic properties}

The sensitivities ${ }^{20}$ of compounds $\mathbf{1 - 3}$ were investigated using the BAM drop hammer, ${ }^{21}$ BAM friction tester ${ }^{21}$ and a OZM electrostatic discharge device. ${ }^{22}$ Compound $\mathbf{1}$ is completely insensitive towards impact and friction stimuli. ${ }^{23}$ In contrast, compounds $\mathbf{2}$ and $\mathbf{3}$ are very sensitive towards impact $(2:<1 \mathrm{~J}$, 3: $3 \mathrm{~J}$ ) and should be handled with great care. With respect to the friction sensitivity 2 (20 N, very sensitive) is much more sensitive than 3 (144 N, sensitive). The electrostatic potentials of $\mathbf{2}$ and $\mathbf{3}$ were illustrated after computing an optimal structure at the B3LYP $631 \mathrm{G}^{*}$ level of theory using the programs Gaussian09, ${ }^{24}$ GaussView 5.0.8 (Fig. 5). ${ }^{25}$ In many publications electrostatic potentials are used to predict sensi tivities of energetic materials. ${ }^{26,27}$ Basically a higher charge separation leads to especially higher friction sensitivity values. Second, in contrast to non energetic organic molecules where the positive potential is larger but weaker in strength, in nitro and azo compounds usually more extensive regions with larger and stronger positive potentials are observed which can be related to the increased impact sensitivities. Especially a higher charge separation can be found for compound 2, which could explain the much higher values in terms of impact and friction sensitivity.

The thermal behavior of $\mathbf{2}$ and $\mathbf{3}$ was investigated using a Linseis PT10 differential scanning calorimeter with a heating

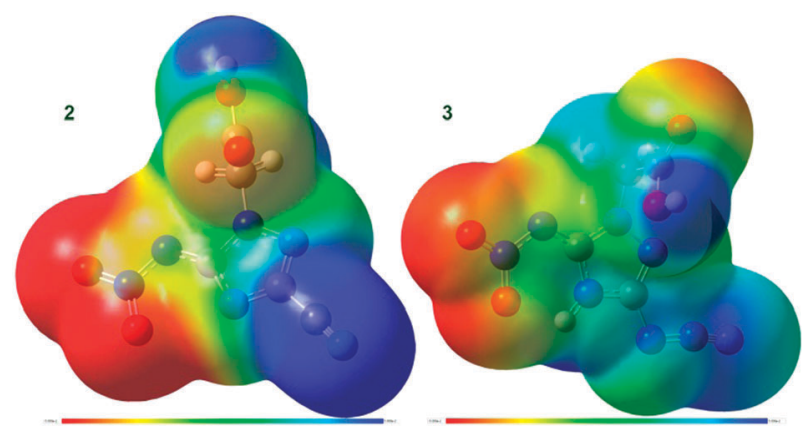

Fig. 5 Calculated (B3LYP/6 31G*) electrostatic potential of 2 (left) and 3 (right). The red regions represent electron rich regions, the blue regions extremely electron deficient regions. 
Table 2 Overview of the sensitivity and performance data of com pounds 13

\begin{tabular}{|c|c|c|c|}
\hline & 1 & 2 & 3 \\
\hline Formula & $\mathrm{C}_{4} \mathrm{H}_{10} \mathrm{~N}_{5} \mathrm{O}_{4} \mathrm{Na}$ & $\mathrm{C}_{4} \mathrm{H}_{3} \mathrm{~N}_{7} \mathrm{O}_{4} \cdot 2 \mathrm{H}_{2} \mathrm{O}$ & $\mathrm{C}_{4} \mathrm{H}_{4} \mathrm{~N}_{8} \mathrm{O}_{4}$ \\
\hline $\mathrm{FW} / \mathrm{g} \mathrm{mol}^{-1}$ & 215.14 & 249.14 & 228.13 \\
\hline $\mathrm{IS}^{a} / \mathbf{J}$ & $>100$ & $<1$ & 3 \\
\hline $\mathrm{FS}^{b} / \mathrm{N}$ & $>360$ & 20 & $>144$ \\
\hline Sieved grain size $/ \mu \mathrm{m}$ & 250500 & $500 \quad 1000$ & $<100$ \\
\hline ESD test ${ }^{c} / \mathbf{J}$ & 1.50 & 0.012 & 0.20 \\
\hline$N^{d}[\%]$ & 32.55 & 39.35 & 49.12 \\
\hline$\Omega^{e}[\%]$ & & -35.32 & -42.08 \\
\hline$T_{\text {dec. }}{ }^{f} /{ }^{\circ} \mathrm{C}$ & 255 & 142 & 125 \\
\hline Density $^{g} / \mathrm{g} \mathrm{cm}^{-3}$ & 1.631 & 1.671 & 1.767 \\
\hline$\Delta_{\mathrm{f}} H_{\mathrm{m}}{ }^{\circ h} / \mathrm{kJ} \mathrm{mol}^{-1}$ & & -264 & 132 \\
\hline$\Delta_{\mathrm{f}} U^{\circ i} / \mathrm{kJ} \mathrm{kg}^{-1}$ & & -960 & 664 \\
\hline EXPLO5.04 values & & & \\
\hline$-\Delta_{E} U^{\circ j} / \mathrm{kJ} \mathrm{kg}^{-1}$ & & 4315 & 4397 \\
\hline$T_{\mathrm{E}}^{k} / \mathrm{K}$ & & 3260 & 3556 \\
\hline$p_{\mathrm{C} \mathrm{J}}^{l} / \mathrm{kbar}$ & & 236 & 263 \\
\hline$D^{m} / \mathrm{m} \mathrm{s}^{-1}$ & & 7674 & 7930 \\
\hline Gas vol. ${ }^{n} / \mathrm{L} \mathrm{kg}^{-1}$ & & 740 & 688 \\
\hline
\end{tabular}

${ }^{a}$ BAM drop hammer. ${ }^{20 b}$ BAM methods. ${ }^{20 c}$ Electric discharge tester. ${ }^{d}$ Nitrogen content. ${ }^{e}$ Oxygen balance. ${ }^{f}$ Decomposition temperature from DSC ( $\left.\beta \quad 5 \quad{ }^{\circ} \mathrm{C}\right) .{ }^{g}$ From $\mathrm{X}$ ray diffraction. ${ }^{h}$ Calculated (CBS 4M) heat of formation. ${ }^{i}$ Energy of formation. ${ }^{j}$ Energy of Explosion. ${ }^{k}$ Explosion temperature. ${ }^{l}$ Detonation pressure. ${ }^{m}$ Deto nation velocity. ${ }^{n}$ Assuming only gaseous products.

rate of 5 degrees per minute. ${ }^{28}$ Unfortunately, 2 and $\mathbf{3}$ have low thermal stabilities $\left(T_{\mathrm{dec}}: \mathbf{2} \quad 142{ }^{\circ} \mathrm{C}, \mathbf{3} \quad 125^{\circ} \mathrm{C}\right)$, which probably excludes any practical applications, $e$.g. as novel lead free primary explosives. ${ }^{29}$ Table 2 summarizes the physico chemical properties of 1-3. For the CHNO compounds the detonation parameters, which were calculated using the program EXPLO5 V5.04, are included. These values are based on the sum formula, heats of formation and the theoretical maximum density obtained by XRD. The heats of formation of $\mathbf{2}$ and $\mathbf{3}$ were calculated by the atomization method (see in ref. 30) based on CBS $4 \mathrm{M}$ electronic energies. The strongly negative value $\left(\Delta_{\mathrm{f}} H_{m}^{\mathrm{o}} \quad-264 \mathrm{~kJ} \mathrm{~mol}^{-1}\right)$ of $\mathbf{2}$ is caused by the inclusion of two molecules of water in the crystal. The crucial calculated detonation parameters of $\mathbf{2}$ and $\mathbf{3}$ are higher in comparison to TNT (trinitrotoluene: $D \quad 7253 \mathrm{~ms}^{-1} ; p_{\mathrm{CJ}}$ $216 \mathrm{kbar}$ ), but lower than those of explosives like PETN (nitropenta: $D \quad 8320 \mathrm{~ms}^{-1}$; $p_{\mathrm{CJ}} 320 \mathrm{kbar}$ ) and RDX (hexogen: $D \quad 8748 \mathrm{~ms}^{-1} ; p_{\mathrm{CJ}} \quad 348 \mathrm{kbar}$ ).

\section{Experimental part}

All reagents and solvents were used as received (Sigma Aldrich, Fluka, Acros Organics) if not stated otherwise. Melting and decomposition points were measured with a Linseis PT10 DSC using heating rates of $5{ }^{\circ} \mathrm{C} \mathrm{min}{ }^{-1}$, which were checked with a Büchi Melting Point B 450 apparatus. ${ }^{1} \mathrm{H}$, ${ }^{13} \mathrm{C}$ and ${ }^{15} \mathrm{~N}$ NMR spectra were measured with a JEOL instrument. All chemical shifts are quoted in ppm relative to TMS $\left({ }^{1} \mathrm{H},{ }^{13} \mathrm{C}\right)$ or nitromethane $\left({ }^{15} \mathrm{~N}\right)$. Infrared spectra were measured with a Perkin Elmer Spektrum One FT IR instrument. Raman spectra were measured with a Perkin Elmer Spektrum 2000R NIR FT Raman instrument equipped with a Nd:YAG laser $(1064 \mathrm{~nm})$. Elemental analyses were performed with a Netsch STA 429 simultaneous thermal analyzer.

\section{Caution!}

The compounds described in this paper are energetic materials and tend to explode under certain conditions. Appropriate safety precautions should be taken at all times, especially when manipulating 2 . Laboratories and personnel should be properly grounded and safety equipments such as Kevlar $^{(}$ gloves, leather coats, face shields, and ear plugs are necessary.

Sodium 1-carboxymethyl-3,5-diamino-1,2,4-triazole dihydrate (1). To a solution of $9.9 \mathrm{~g}(0.10 \mathrm{~mol}) 3,5$ diamino $1,2,4$ triazole and $8.0 \mathrm{~g}(0.20 \mathrm{~mol})$ sodium hydroxide in $500 \mathrm{~mL}$ methanol at $60{ }^{\circ} \mathrm{C}$ was added slowly $15.3 \mathrm{~g}(0.11 \mathrm{~mol})$ bromoacetic acid. After refluxing the solution for 16 hours the solvent was removed under vacuum. The beige colored residue was dissolved in $200 \mathrm{~mL} \mathrm{H}_{2} \mathrm{O}$ and the $\mathrm{pH}$ of the solution was reduced to less than 2 with concentrated hydrochloric acid $(25 \mathrm{~mL}, 37 \%)$. After recrystallization from $\mathrm{H}_{2} \mathrm{O}$ the beige solid was obtained and dried under vacuum. Yield: 87\%. Mp: $255{ }^{\circ} \mathrm{C}$ (DSC, $5 \mathrm{~K} \mathrm{~min}^{-1}$ ); ${ }^{1} \mathrm{H}$ NMR (DMSO $\left.d_{6}\right): 4.35\left(s, 2 \mathrm{H}, \mathrm{CH}_{2}\right) ;{ }^{13} \mathrm{C}$ NMR (DMSO $\left.d_{6}\right): 169.9$ (COO), $160.0 \quad\left(C \mathrm{NH}_{2}\right), \quad 155.0$ $\left(\mathrm{CNH}_{2}\right), 47.5\left(\mathrm{CH}_{2}\right)$; Raman $\left(200 \mathrm{~mW}, 25^{\circ} \mathrm{C}, \mathrm{cm}^{-1}\right): 3176$ (20), 2984 (50), 2945 (86), 1671 (60), 1642 (45), 1465 (56), 1430 (47), 1394 (83), 1311 (66), 1270 (42), 1152 (40), 1078 (29), 1025 (43), 918 (63), 871 (73), 825 (23), 814 (28), 766 (39), 661 (100), 598 (37), 536 (40), 449 (40), 354 (64), 307 (58), 272 (52); IR (Diamond ATR, cm ${ }^{-1}$ ): 3362 (m), 3278 (m), 3172 (m), 3063 (m), 2983 (m), 1772 (vw), 1664 (vs), 1605 (m), 1582 (s), 1533 (m), 1472 (m), 1429 (m), 1391 (s), 1305 (m), 1265 (m), 1151 (w), 1082 (w), $1020(\mathrm{~m}), 960(\mathrm{w}), 911(\mathrm{w}), 868(\mathrm{w}), 762(\mathrm{w}), 684(\mathrm{~m}), 660$ (m), 614 (vw); elemental analysis $\mathrm{C}_{4} \mathrm{H}_{8} \mathrm{~N}_{5} \mathrm{NaO}_{3}\left(197.13 \mathrm{~g} \mathrm{~mol}^{-1}\right)$ calc.: C 24.37, H 4.09, N 35.53\%; found: C 24.40, H 3.83, N $34.91 \%$; BAM drop hammer: > $100 \mathrm{~J}$ (250 $500 \mu \mathrm{m})$; BAM friction tester: $>360 \mathrm{~N}(250500 \mu \mathrm{m})$; ESD: $1.5 \mathrm{~J}(250500 \mu \mathrm{m})$.

1-Carboxymethyl-3-diazonio-5-nitrimino-1,2,4-triazole dihydrate (2). At $-10{ }^{\circ} \mathrm{C}, 329 \mathrm{mg}(1.5 \mathrm{mmol})$ of sodium 1 carboxy methyl 3,5 diamino 1,2,4 triazole dihydrate was slowly added to $1 \mathrm{~mL}$ nitric acid $(100 \%)$. After stirring for 72 hours at RT the solution was poured onto ice. The orange red crystals, which formed after one day, were filtered and washed with $\mathrm{Et}_{2} \mathrm{O}$. Yield: $28 \%$. Mp: $>58{ }^{\circ} \mathrm{C}\left(\mathrm{H}_{2} \mathrm{O}\right),>93{ }^{\circ} \mathrm{C}\left(\mathrm{H}_{2} \mathrm{O}\right),>142{ }^{\circ} \mathrm{C}$ (dec., DSC $5 \mathrm{~K} \mathrm{~min}^{-1}$ ); ${ }^{1} \mathrm{H}$ NMR (DMSO $\left.d_{6}\right)$ : $4.93\left(s, 2 \mathrm{H}, \mathrm{CH}_{2}\right)$; ${ }^{13} \mathrm{C}$ NMR (DMSO $\left.d_{6}\right)$ : $167.4(\mathrm{COOH}), 155.9(\mathrm{CNN}), 151.2$ $\left(\mathrm{CNHNO}_{2}\right), 49.2\left(\mathrm{CH}_{2}\right)$; Raman $\left(100 \mathrm{~mW}, 25^{\circ} \mathrm{C}, \mathrm{cm}^{-1}\right): 3005$ (3), 2963 (5), 2275 (100), 1516 (35), 1473 (51), 1397 (8), 1358 (5), 1264 (26), 1201 (25), 1139 (50), 1038 (22), 1019 (6), 972 (10), 938 (4), 790 (4), 761 (9), 729 (2), 483 (3), 455 (4), 376 (3), 293 (7); IR (Diamond ATR, $\mathrm{cm}^{-1}$ ): $3531(\mathrm{~m}), 3298(\mathrm{~m}), 3004(\mathrm{~m}), 2529(\mathrm{w})$, 2274 (s), 1992 (w), 1730 (s), 1604 (w), 1522 (s), 1468 (m), 1421 (m), 1413 (7), 1408 (m), 1347 (m), 1290 (s), 1229 (vs), 1134 (m), 1018 (m), 970 (w), 937 (w), 898 (w), 789 (m), 778 (m), 760 (w), 725 (w), $670(\mathrm{w}), 648(\mathrm{w})$; EA: $\mathrm{C}_{4} \mathrm{H}_{7} \mathrm{~N}_{7} \mathrm{O}_{6}\left(249.14 \mathrm{~g} \mathrm{~mol}^{-1}\right)$ calc.: C 19.28, H 2.83, N 39.35\%; found: C 19.56, H 2.45, N 39.18\%; BAM drop hammer: <1.0 J (500 $1000 \mu \mathrm{m})$; BAM friction tester: $20 \mathrm{~N}(5001000 \mu \mathrm{m})$; ESD: $12 \mathrm{~mJ}(5001000 \mu \mathrm{m})$.

1-Carboxymethyl-3-azido-5-nitrimino-1,2,4-triazole (3). $250 \mathrm{mg}$ (1.2 mmol) of 1 carboxymethyl 3 azo 5 nitrimino 1,2,4 triazole dihydrate was dissolved in $5 \mathrm{~mL}$ water. At $0{ }^{\circ} \mathrm{C}, 77 \mathrm{mg}$ 
(1.2 mmol) of sodium azide, dissolved in $5 \mathrm{~mL}$ water, was added slowly with stirring. After stirring for 20 hours at RT the water was removed under vacuum. The solid was dissolved in acetone, the salt was filtered off and the acetone was removed under vacuum to yield pure $\mathbf{3}$ as a yellow solid. After recrystalli zation from water yellow crystals suitable for $\mathrm{X}$ ray analysis were formed. Yield: $85 \%$. Mp: $125{ }^{\circ} \mathrm{C}$ (dec., DSC, $5 \mathrm{~K} \mathrm{~min}{ }^{-1}$ ); ${ }^{1} \mathrm{H}$ NMR (DMSO $\left.d_{6}\right): 4.81\left(s, 2 \mathrm{H}, \mathrm{CH}_{2}\right) ;{ }^{13} \mathrm{C}$ NMR (DMSO $\left.d_{6}\right)$ : $167.8(\mathrm{COOH}), 150.0(\mathrm{CNN}), 149.8(\mathrm{CNN}), 48.9\left(\mathrm{CH}_{2}\right) ;{ }^{14} \mathrm{~N}$ NMR (DMSO $\left.d_{6}\right)$ : $-18\left(\mathrm{NNO}_{2}\right)$; Raman $\left(100 \mathrm{~mW}, 25^{\circ} \mathrm{C}, \mathrm{cm}^{-1}\right)$ : 2994 (4), 2956 (9), 2859 (6), 2159 (5), 1579 (100), 1510 (8), 1448 (11), 1423 (9), 1404 (6), 1318 (8), 1248 (5), 1135 (4), 1035 (31), 962 (4), 900 (9), 810 (12), 748 (4), 678 (3), 652 (4), 575 (3), 503 (3), 451 (4), 387 (4), 340 (7), 271 (15); IR (Diamond ATR, cm ${ }^{-1}$ ): 3044 (m), 2992 (m), 2953 (m), 2558 (m), 2248 (w), 2153 (vs), 1749 (m), 1723 (m), 1563 (vs), 1508 (m), 1420 (s), 1397 (s), 1299 (s), 1238 (vs), 1218 (vs), 1165 (m), 1130 (m), 1033 (m), 1018 (m), 916 (m), 892 (m), $774(\mathrm{~m}), 747(\mathrm{~m}), 718(\mathrm{~m}), 657(\mathrm{~m})$; elemental analysis: $\mathrm{C}_{4} \mathrm{H}_{4} \mathrm{~N}_{8} \mathrm{O}_{4}\left(228.04 \mathrm{~g} \mathrm{~mol}^{-1}\right)$ calc.: C 21.06, $\mathrm{H} \mathrm{1.77,} \mathrm{N} \mathrm{49.12 \% ;}$ found: C 22.20, H 1.78, N 47.00\%; BAM drop hammer: $3 \mathrm{~J}$ $(<100 \mu \mathrm{m})$; BAM friction tester: $>144 \mathrm{~N}(<100 \mu \mathrm{m})$; ESD: $0.2 \mathrm{~J}(<100 \mu \mathrm{m})$.

\section{Conclusions}

Energetic materials containing carboxyl substituents are used to develop biosensor detection devices for explosive and hazardous materials. The nitration at $-10{ }^{\circ} \mathrm{C}$ of sodium 1 carboxymethyl 3,5 diamino 1,2,4 triazole dihydrate (1) yielded highly sensitive 1 carboxymethyl 3 diazonio 5 nitrimino 1,2,4 triazole (2), which was also characterized by single crystal $\mathrm{X}$ ray diffraction. The molecular structure shows a zwitterionic constitution which can be also drawn by expedient Lewis representation. The positive charge of the diazonio group is balanced by the negatively charged electronegative triazole ring. DFT calculation and the depiction of the electrostatic potential confirm this charge separation which causes high sensitivity towards impact and friction also in its dehydrated form. The reactivity of the diazonio substituent was explored by the reaction with sodium azide. After release of dinitrogen 1 carboxymethyl 3 azido 5 nitrimino 1,2,4 triazole (3) was formed which shows lower sensitivity values, but also in the range of primary explosives. However, the diazonio compound shows higher thermal stability ( $\left.T_{\mathrm{dec}}: 2 \quad 142{ }^{\circ} \mathrm{C}\right)$ in comparison to 3 ( $\left.T_{\text {dec: }}: 125^{\circ} \mathrm{C}\right)$. Calculated detonation parameters are higher than those of TNT but lower than those of PETN and RDX.

\section{Notes and references}

1 J. C. Oxley, J. L. Smith, E. Resende, E. Pearce and T. Chamberlain, J. Forensic Sci., 2003, 48, 19.

2 (a) C. A. Heller, S. R. Greni and E. D. Erickson, Anal. Chem., 1982, 54, 286 289; (b) Y. Zhang, W. R. Seitz and C. L. Grant, Anal. Chim. Acta, 1989, 217, 217 227; (c) S. Stevanovic and M. Mitrovic, Int. J. Environ. Anal. Chem., 1990, 40, 69 76; (d) T. F. Jenkins and M. E. Walsh, Talanta, 1992, 39, 419 428; (e) R. T. Medary, Anal. Chim. Acta, 1992, 258, 341 346; (f) D. Royds, S. W. Lewis and A. M. Taylor, Talanta, 2005, 67, 262 268; (g) J. Almog, J. Forensic Sci., 2006, 51, 12281234.

3 R. G. Smith, N. D'Souza and S. Nicklin, Analyst, 2008, 133, 571584

4 Selected papers for the Sixth World Congress on Biosensors, Biosens. Bioelectron., 2001, 1166, 6091142.
5 K. Y. Lee, L. B. Chapman and M. D. Coburn, J. Energ. Mater., 1987, 5, 27.

6 E. Garcia and K. Y. Lee, Acta Crystallogr., Sect. C: Cryst. Struct. Commun., 1992, 48, 16821683.

7 F. Einberg, J. Org. Chem., 1970, 35, 39783980.

8 CrysAlisPro Oxford Diffraction Ltd., Version 171.33.41, 2009.

9 SIR 92, 1993, A program for crystal structure solution, A. Altomare, G. Cascarano, C. Giacovazzo and A. Guagliardi, J. Appl. Crystallogr., 1993, 26, 343.

10 G. M. Sheldrick SHELXS 97, Program for Crystal Structure Solution, Universitat Gottingen, 1997.

11 A. L. Spek, PLATON, A Multipurpose Crystallographic Tool, Utrecht University, Utrecht, The Netherlands, 1998.

12 L. J. Farrugia, J. Appl. Crystallogr., 1999, 32, 837838.

13 Empirical absorption correction using spherical harmonics, implemented in SCALE3 ABSPACK scaling algorithm (CrysAlisPro Oxford Diffraction Ltd., Version 171.33.41, 2009).

14 K. R. Tarantik, dissertation, Ludwig Maximilian University, Munich, 2010.

15 J. Glinka, D. Fiscus, C. B. Rao and H. Shechter, Tetrahedron Lett., 1987, 28, 32213224.

16 S. D. Stepanov and M. S. Pevzner, Zh. Org. Khim., 1989, 25, 2013.

17 (a) G. Daidone, B. Maggio, M. V. Raimondi, G. Bombieri, N. Marchini and R. Artali, Heterocycles, 2005, 65, 2753; (b) X. M. Zou, F. Z. Hu and H. Z. Yang, Chin. J. Struct. Chem., 2004, 23, 149; (c) I. Leban, B. Stanovnik and M. Tisler, Acta Crystallogr., 1978, B34, 293; (d) A. F. Cameron, N. J. Hair and D. G. Morris, J. Chem. Soc., Perkin Trans. 1, 1972, 1331.

18 S. Brase, C. Gil, K. Knepper and V. Zimmermann, Angew. Chem., 2005, 117, 53205374.

19 M. Hesse, H. Meier and B. Zeeh, Spektroskopische Methoden in der organischen Chemie, Thieme Verlag, Stuttgart, 7 edn, 2005.

20 M. Sućeska, Test Methods for Explosives, Springer, New York, 1995, p. 21 (impact), p 27 (friction).

21 (a) http://www.reichel partner.de; $(b)$ www.bam.de.

22 OZM research, Czech Republic, http:// www.ozm.cz/testing instruments/small scale electrostatic discharge tester.htm.

23 Test methods according to the UN Recommendations on the Transport of Dangerous Goods, Manual of Tests and Criteria, fourth revised edition, United Nations Publication, New York and Geneva 2003, Impact: Insensitive $>40 \mathrm{~J}$, less sensitive $\geq 35 \mathrm{~J}$, sensitive $\geq 4 \mathrm{~J}$, very sensitive $\leq 3 \mathrm{~J}$; Friction Insensitive $>360 \mathrm{~N}$, less sensitive $360 \mathrm{~N}$, sensitive $<360 \mathrm{~N}$ a. $>80 \mathrm{~N}$, very sensitive $\leq 80 \mathrm{~N}$, extremely sensitive $\leq 10 \mathrm{~N}$.

24 M. J. Frisch, G. W. Trucks, H. B. Schlegel, G. E. Scuseria, M. A. Robb, J. R. Cheeseman, G. Scalmani, V. Barone, B. Mennucci, G. A. Petersson, H. Nakatsuji, M. Caricato, X. Li, H. P. Hratchian, A. F. Izmaylov, J. Bloino, G. Zheng, J. L. Sonnenberg, M. Hada, M. Ehara, K. Toyota, R. Fukuda, J. Hasegawa, M. Ishida, T. Nakajima, Y. Honda, O. Kitao, H. Nakai, T. Vreven, J. A. Montgomery, Jr., J. E. Peralta, F. Ogliaro, M. Bearpark, J. J. Heyd, E. Brothers, K. N. Kudin, V. N. Staroverov, R. Kobayashi, J. Normand, K. Raghavachari, A. Rendell, J. C. Burant, S. S. Iyengar, J. Tomasi, M. Cossi, N. Rega, J. M. Millam, M. Klene, J. E. Knox, J. B. Cross, V. Bakken, C. Adamo, J. Jaramillo, R. Gomperts, R. E. Stratmann, O. Yazyev, A. J. Austin, R. Cammi, C. Pomelli, J. W. Ochterski, R. L. Martin, K. Morokuma, V. G. Zakrzewski, G. A. Voth, P. Salvador, J. J. Dannenberg, S. Dapprich, A. D. Daniels, O. Farkas, J. B. Foresman, J. V. Ortiz, J. Cioslowski and D. J. Fox, Gaussian 09, Revision A.1, Gaussian Inc., Wallingford, CT, 2009.

25 GaussView, Version 5, Roy Dennington, Todd Keith and John Millam, Semichem Inc., Shawnee Mission KS, 2009.

26 B. M. Rice and J. J. Hare, J. Phys. Chem., 2002, 106A, 1770.

27 (a) P. Politzer, J. S. Murray, J. M. Seminario, P. Lane, M. E. Grice and M. C. Concha, J. Mol. Struct., 2001, 573, 1; (b) J. S. Murray, P. Lane and P. Politzer, Mol. Phys., 1995, 85, 1.

28 Linseis GmbH, Germany, http://www.linseis.com, DSC calibrated with pure indium and zinc; measurements of $12 \mathrm{mg}$ of the compounds in pressed $\mathrm{Al}$ container, containing a hole $(0.1 \mathrm{~mm})$ for the gas release in a continuous nitrogen flow.

29 N. Fischer, T. M. Klapotke and J. Stierstorfer, J. Energ. Mater., 2011, 29, 6174.

30 T. Altenburg, T. M. Klapotke, A. Penger and J. Stierstorfer, Z. Anorg. Allg. Chem., 2010, 636, 463471. 